811.163.41'42

303.621.32:654.191

https://doi.org/10.18485/sj.2017.22.1.34

МАРКО М. ЈАНИЋИЈЕВИЪ ${ }^{*}$

Државни универзитет у Новом Пазару

Департман за филолошке науке
Оригинални научни рад

Примљен: 21. 08. 2016.

Прихваћен: 15. 12. 2016.

\title{
ДА/НЕ ПИТАЬА И ИЗБОРНА ПИТАЬА У ФУНКЦИЈИ ПАРЦИЈАЛНИХ (ПОСЕБНИХ): ПРАГМАЛИНГВИСТИЧКИ ПРИСТУП
}

Циљ рада је преиспитивање односа између неких типова питања са да/не одговорима, односно изборних (дисјунктивних) питања, и ситуационог опсега (тоталног/парцијалног) који обухвата тражена (непозната) информација у њима. Теоријско-методолошки оквир спроведене анализе чине лингвистичка прагматика, нарочито анализа информационе структуре, и синтаксичка семантика, аграђу знатандео Колекције „Одговори”, едиције интервјуа биографске оријентације са истакнутим културним посленицима. Утврђују сетипови да/не питањаза које се показује да, према ситуационом опсегу на који се односе, типично функционишу као парцијална (посебна) питања. За изборна питања се такође показује да типично испољавају карактер парцијалних (посебних), а у неким случајевиматоталних (општих). Отуда се, у случајевима парцијалних (посебних) да/не и изборних питања, може говорити о њиховој(међусобној и) граматичкој синонимији са тзв. заменичкимпитањима.

Кључне речи: да/не питања, изборна (алтернативна) питања, парцијална (посебна) питања, прагматика, информациона структура, фокус, пресупозиција, индиректан исказ.

"trupko@outlook.com 


\section{1. УВОД}

Предмет рада су превасходно упитни искази којинису у форми тзв. заменичких питања, тј. немају као маркер упитности заменицу или заменички прилог, односно прилошки израз, а функционишу као тзв. парцијална (посебна) питања. Парцијална, тј. посебна, питања су она код којих јенепознат неки део пропозиције, за који изискују доделу семантичког садржајау одговору. Циљ рада је преиспитивање односа између неких типова питања са да/не одговорима, односно изборних (дисјунктивних) питања, и ситуационог опсега (тоталног/парцијалног) који обухвата тражена (непозната) информација у њима. На тај начин показује се да одређени типови да/не питања и изборна питања под извесним условима функционишу као парцијална питања, синонимно са заменичким питањима.

Теоријско-методолошки оквир спроведене анализе чине лингвистичка прагматика - нарочито анализа информационе структуре - и синтаксичка семантика. Грађу за истраживање представља знатан део Колекције „Одговори”, едиције од преко 210 књига интервјуа биографске оријентације, које је познати новинар и публициста, Милош Јевтић, водио са истакнутим научницима, уметницима и другим културним посленицима. Знатним делом радијског порекла (емисија „Гост Другог програма” Радио Београда), Колекција је карактеристична и по питањима постављеним у виду „батерије”, комплекса упитних реченица, често са уводом (в. и Јанићијевић 2013), али се налазе и засебна кратка (пот)питања (од једне реченице) различитог типа. Својим жанром, разноврсношћу и обимом Колекција представља интересантну грађу и за сврхе овог истраживања.

Школска је подела на општа и посебна питања, и она у суштини одговара критеријуму опсега ситуације на који се питање односи (в., нпр.: Пипер 2005: 672; Станојчић и Поповић 1992: 334-335). Сродна је подела која се изводи према типу информације која се тражи од саговорника, а обухвата: (a) тотална питања, којима се тражи информација о целини исказане ситуације, (б) парцијална, којима се тражи информација о једном сегменту исказане ситуације, и (в) изборна питања, којима се од понуђених референата захтева избор траженог референта (уп.: Поповић 2005: 1044-1047; Ковачевић 2012: 68). Тотална питања су питања са целовитом пропозицијом, парцијална са пропозитивном функцијом, а изборна са потпуном пропозицијом и њеним дисјунктом (Мирић 2013: 46-47). Аналогна је и класификација према начину на који је дефинисан скуп могућих одговора (Хадлстон 1994: 416), која разликује: (а) поларна питања (енгл. polar questions), која подразумевају скуп од два одговора, од којих један одговара пропозиционалном садржају питања, а други његовом поларном опозиту; (б) питања са променљивом (енгл. variable questions), која садрже променљиву (варијаблу) коју одговор треба да замени 
одређеном вредношћу; и (в) алтернативна питања (енгл. Alternative questions), која садрже скуп алтернативних одговора.

Терминима тотална, парцијална и изборна питања одговарају заступљенији термини (ситуативно) општа, (ситуативно) посебна питања и алтернативна питања (уп.: Ковачевић 2012: 68), односно термини поларна, питања са променљивом и алтернативна питања,а састановишта логичко-граматичке структуре, генерално гледано, и термини да/не питања (енгл. yes/no questions), х-питања (нпр. Лајонс 1977: 757), познатијакаозаменичка(енгл. Wh-questions), и дисјунктивна питања. Тотална питања неретко се посматрају као изведена од изборних (Бартелс 2013: 83; уп. Мусићево становиште наведено у: Мирић 2013: 31), тако да је, нпр., у тоталном питању Је ли се вратио? подразумевана структура изборног питања Је ли се вратио или није?.

Неки аутори остају при двочланој подели питања, не видећи изборна питања као засебан тип. Лајонс (1977: 762) види две врсте дисјунктивних питања, која се у енглеском језику (а и у српском) разликују по интонацији. Наиме, он примећује да дисјунктивна питања типа Јеси ли Британаи или Американац? могу представљати (а) (отворена) да/не питања, ако пресупонирају дисјункцију контрадикторних пропозиција Британац си или Американац и Ниси Британаи или Американац, или (б) ограниченах-питања, ако је скуп могућих вредности за х ограничен на оне понуђене у питању, које пресупонира истинитост једне и само једне од њих (Британац си и Американац си). Прва могућност коју наводи Лајонс одговара тоталном (општем) питању, а друга ограниченом парцијалном (посебном) питању, тј., практично, изборном (алтернативном) питању. Слично, Свит (2014: 174) алтернативна питања сматра подврстом посебних питања, која са другим посебним питањима има заједничку и силазну интонацију, као индикатор еквиваленције посебних питања са командама ${ }^{1}$. Холмберг (2015: 11), такође, говори о (синтаксичким) сличностима између алтернативних и заменичких питања. С друге стране, Свит (н. д.: 174-175) у форми алтернативних питања види заједничку карактеристику са општим питањима, напомињући да постоје и алтернативна општа питања, емфатичног карактера, као у примеру Јеси ли спреман, или ниси?, на која се одговора као на општа питања.

Кифер (1980) се бави неким типовима да/не питања на која у нормалним околностима није прикладно одговорити само са да или само са не. Реч је о пре свега, о да/не питањима са фокусом (енгл. focus questions), за која Кифер показује да се могу интерпретирати као заменичка. Од питања са фокусом он посебно разматра тзв. раздвојена питања (енгл. cleft questions), одрична питања са фокусом, питања са адвербијалима за начин, квантификаторима и сродним

${ }^{1}$ Нпр., посебно питање Када је домао? еквивалентно је са Знам да је у неко времедомао -желим да знам када.(слично је код алтернативних питања). 
изразима, затим (зависно)сложена питања са фокусом, каои питања која назива идентификационим (енгл. identification questions, нпр.Jе ли ово твоја cecmpa?). Осим питања са фокусом Кифер (н. д.) издваја и егзистенцијална питања са неодређеном заменицом и питања са глаголом знати у главној клаузи,као питања на која се не може прикладно одговорити са да и која под одређеним околностима такође могу бити интерпретирана као заменичка.

Дакле, као својеврстан вид граматичке метафоре, парцијална или посебна питања могу бити у форми да/не питања, рецимо Је ли пошта овде негде? или Да ли неко зна песму напамет?. Такође, да/не питање може изгледати као изборно (уп. и Биезма и Ролинс 2012), нпр. Је л' идеш на скијање или санкање? (подвучени израз који носи реченични акценат).

У истраживању користимо семантички појам фокуса и појам пресупозиције у прагматичком смислу, као компонената информационе структуре. Семантички (информациони) фокус „део је реченице који одговара на релевантно заменичко питање (имплицитно или експлицитно) у одређеном контексту у коме се реченица употребљава"2 (Гандел 1999: 295). Пресупозицијау прагматичком смислу је скуп пропозиција лексичко-граматички евоцираних уреченицикоје говорник узима као део знања заједничког са говорником(уп.Ламбрехт 1994: 52). Пресупозиција питања уопште је тражење информације; да/не питањауз то пресупонирају и дисјункцију опречних пропозиција,заменичка постојање непознатог елемента, израженог заменичким изразом,а алтернативна истинитост једне и само једне од алтернатива (в., нпр., Левинсон 1983: 184; Картунен 1977).

\section{2. АНАЛИЗА}

2.1. Прелиминарни оглед. За (ситуативно) општа питања Пипер (2005: 672 ) даје примере 1a, 2a и 3а. Међутим, ти примери, како ћемо показати, одговарају (и) другим типовима питања у односу према ситуативном опсегу.

У примеру 1 може бити случај (1б) да је пресупозиција само тражење информације, а пада киша пропозиција за коју се тражи истинитосна вредност, односно да је заиста реч о општем (тоталном) питању.Такође, може бити случај (1в) - рецимо, у ситуцији где саговорник са влажном одећом улази у кућу - да је пресупозиција да нештопада, а да фокус носи конституент киша. Тада је, дакле, тражена информација о једном сегменту ситуације, а остатак ситуације је пресупониран, баш као код заменичких, односно парцијалних (посебних) питања. Одговарајуће заменичко питање би гласило Шma naдa?

2 "Semantic focus is the part of the sentence that answers the relevant wh-question(implicit or explicit) in the particular context in which the sentence is used." 
(са истоветном пресупозицијом да нешто пада). Слично је у примеру 2, који представља декларативно питање. Могућа је, тако, варијанта (2б) да је изнета пропозиција за коју се тражи потврда истинитости, тј. варијанта да је заиста реч о општем питању. Другачија могућност (2в) подразумевала бипресупозицију да саговорници јесу негде били, при чему би фокус био на месту (у Будви), а што би било еквивалентно одговарајућем заменичком питању (У ком сте месту били?), односно питању парцијалног карактера у погледу захватања ситуације. Овде не требаиспуштати из вида даје у говорењу одговарајући тип питања обележен интонацијом; интерпретација примера у 1 и 2 као парцијалних питања индицирана је реченичним акцентомна елементу који је у фокусу (киша; у Будви).

У примеру пак алтернативног питања (3), могућа је, сматрамо, само једна интерпретација (3б). Наиме, како је пресупозиција алтернативног питања истинитост једне и само једне од алтернатива, а у примеру 3 обе (дошли/одлазите) имплицирају кретање, следи да је пресупонирана радња кретање саговорника, док је упитансамо смер кретања. Другим речима, питање се односи само на један аспекат ситуације, док је остатак ситуације унапред дата, позната информација, што је еквивалентно случају парцијалних (посебних) питања. Дакако, наведена пресупозиција може бити поништена, одбацивањем обе алтернативе, или пак избором обе, као у датом одговору (3б).

[1] (а) Да ли пада киша?

(б) Да ли пада киша? - Не пада (киша).

(в) Да ли пада киша? [Шта пада?] - Суснежица.

[2] (а) Били сте у Будви?

(б) Били сте у Будви? - Нисмо тамо свраћали.

(в) Били сте у Будви? [У ком месту сте били?] - У Бару.

[3] (а) Јесте ли дошли или одлазите?

(б) Јесте ли дошли или одлазите? - Само што смо дошли, а већ желимо да одемо.

Поставља се питање може ли алтернативно питање бити тотално у погледу ситуационог опсега, на шта настојимо да одговоримо у одељку 2.4.

2.2. Граматичка синонимија заменичких, да/не и дисјунктивних питања. У примеру комплексног (упитног) исказа 4 заступљена су директни упитни исказиу форми сва три главна типа питања (4в-ђ), уз један случај (4б) који се може тумачити као индиректан упитни исказ. Заменичко питање илуструје 4в, дисјунктивно 4г, а да/непитање 1д и 1ђ. Алтернативни карактер питања $1 г$ неспоран је с обзиром на изражену дисјункцију две контрадикторне про- 
позиције. С друге стране, алтернативни карактер питања 1 д није вероватан, и поред две дисјункције, будући да је прва (скривени или затурени од јавности), остварена као апозитив, пре свега,у другом плану, што не одговара информационој структури алтернативног питања, акод друге (значајни стари рукописи или ретка нека стара издања) је непознато,у првом реду, постојање референата оба дисјункта (с обзиром на питање 4г)да би се између њих уопште и постављало питање.

[4] [а] Сада бисмо у разговор увели шире теме, пре свега оне које су везане за Ваше деловање.

[б] Хтели бисмо, прво, да нам изнесете своје погледе о историји наше књиге, нарочито старе и ретке књиге.

[в] Који би били најважнији датуми у једној таквој историји?

[г] Такође, да ли је све истражено или има и празнина?

[д] Да ли се, заправо, може очекивати да још увек негде чаме, скривени или затурени од јавности, значајни стари рукописи или ретка нека стара издања?

[ち] Уосталом, да ли Ваше слутње говоре да на тим пословима још није све завршено? (Јевтић 1998: 139)

Постављајући питања да/не типа, интервјуер (који заступа и аудиторијум) генерално не очекује пукиодговор да/не типа, већ таква питања више користи као подстицај за саговорника да пружи потпунији увид у проблематику питања. У одломку 4 питања 4г-ђ смисаоно су врло сродна, и у случају постојања поменутих неистражених ствари (друге алтернативе у 4г, односно потврдног одговора на 4д-ђ) очекивали би се у одговору и детаљи о чему је реч; другим речима очекивали би се посебни одговори. У том смислу, дато алтернативно питање и да/не питања показују међусобне сличности, али и сличности са заменичким питањима, тако даби се могло говорити и о (граматичкој) синонимији тих типова питања.

2.3. Да/не питања у функиији париијалних (посебних). Међу да/не питањима у функцији парцијалних (посебних)могла би се издвојити (а) она на која се не може успешно одговоритипуким $\partial a$, и (б) она која се не може успешно одговорити пуким не. Из прве групе најзаступљенија су питања егзистенцијалног типа са неодређеним заменицама (примери 5, 6 и 7), са којима су сродна питања тог типа у којима се неодређена заменица могла употребити $\left(\right.$ пример $8^{3}$ ).Те заменице, у ствари, представљају елемент ситуације који је

\footnotetext{
${ }^{3}$ Овај пример се може парафразирати, нпр., овако:Да ли има [неких] научних установа из других делова тадашње Југославије са којима сте у том широко заснованом послу остваривали сарадњу?.
} 
непознат и за који се пита (што је еквивалентно парцијалним питањима). Тај елемент може бити маркиран и општом заменицом (пример 9) или општим прилогом (10), што се, опет, може преформулисати као егзистенцијално питање (Постоји ли нешто што није било уобичајено ...?, односно, Да ли некад није било како сте замишљали и желели?), а што би било еквивалентно одричним заменичким питањима, те у таквим случајевима пуки одговор не не био адекватан (тзв. декларативно питање у пр. 9 је и врло сугестивно у погледу очекиваног одговора).

[5] Да ли се може учинити нешто да се култ читања обнови... [ $\approx$ Шma се може учинити да се култ читања обнови?] (Јевтић 1990: 78-79)

[6] Da li među njima [песмама] postoji neka koja Vas, prema sopstvenom osećanju, najcelovitije - kao pesnika- predstavlja? [ $\approx$ Koja Вас песма (ако таква постоји) према сопственом осећању, најцеловитије - као песника-представља?] (Јевтић 2000в)

[7] Да ли сте - у току студија - упознали, будући да сте били и сами песник, и неке песнике, славне у то време? [Које сте песнике, славне у то време- у току студија - упознали, будући да сте били и сами песник?] (Јевтић 1994б: 29)

[8] Да ли сте у том широко заснованом послу остваривали сарадњу и с [неким] научним установама из других делова тадашње Југославије? $[\approx C$ којим научним установама из других делова тадашње Југославијесте у том широко заснованом послу остваривали сарадњу?] (Јевтић 2003б: 107)

[9] Све је било уобичајено, и све је, значи, обећавало најбоље? [ $\approx$ Шma (евентуално) није било уобичајено ...?] (Јевтић 2004: 126)

[10]Да ли је увек било како сте замишљали и желели? [ $\approx a д a$ (можда) није било како сте замишљали и желели?] (Јевтић 2000б: 59)

С обзиром на реченичнуфункцију којој одговара непознати ситуациони елемент, може се говорити о субјекатским $(5,6,9)$, објекатским (7), адвербијалним (8 и 10), као и опредикатским/предикативним (пример дат у Уводу, Је ли пошта овде негде?, еквивалентан са: Где је пошта) питањима, када је реч о одговарајућим реченичним члановима, односно њиховим деловима (као детерминаторима).

Слично, код питања са предикатима сазнања, каоу примерима 11, 12 и 13 , сами потврдни одговори на питања не би били задовољили интервјуера и аудиторијум, јер та питања, у ствари, функционишу као индиректна парцијална питања која одговарају зависно-упитним клаузама. Сродне примере налазимо и са предикатима говорења (14). Примери 11-14, у ствари, кореспондирају са 
егзистенцијалним питањима: Има(те) ли (са)знања/информащија/слутње/воље да нам рекнете... Индиректност питања у датим примерима служи за постизање вишег нивоа учтивости. ${ }^{4}$

[11] Dali znate koliko ste do sada napisali stihova? [ $\approx$ Колико сте до сада написали стихова?] (Јевтић 2000в)

[12] ... да ли имате информачија колико се данас преводи и уопште колико се зна о југословенској књижевности у Мађарској? [ ККолико се данас преводи и уопште колико се зна о југословенској књижевности у Мађарској] (Јевтић 1991: 75)

[13] Слутите ли - пошто говорите о крају рата - када ће престати сукоби? [ح Када ће престати сукоби?] (Јевтић 1994а: 119)

[14] Да ли бисте нам рекли - када смо већ код Медиале - како је она деловала, да кажемо, у пракси, у животу? [ح Како је она деловала, да кажемо, у пракси, у животу?] (Јевтић 1992: 39)

У примерима 15-22 пак одричан одговор сам био би неадекватан, а реч је - с обзиром, пре свега, на примену Грајсове максиме квантитета ${ }^{5}$ (информативност) у контексту дате (под)теме и типа интервјуа - о питањима са фокусом. Опет можемо говорити, у зависности од тога у којој реченичној функцији се остварује непознати појам, осубјекатским $(15,16)$, предикативним (17), објекатским (18, уп. пр. 34), адвербијалним (начинским, узрочним,временским, као, редом, у примерима 19, 20 и 21, и сл.), али и питањима која бисмо могли означити као глаголска предикатска (22), будући да обухватају глаголски предикат. У примеру 15 познато је (из претходног дискурса) да је саговорник дошао у Београд и то (тачније, да га је нешто довело у Београд) је пресупозиција питања, а фокус је на томе шта га је тамо довело, односно то је непозната (информација); у декларативном питању у примеру 16 пресупозиција је да је нешто следило, а фокус је управо на томе шта је то следило, ако не повратак; у пр. 17 такође је претходно речено да је саговорник био у Гетеборгу, а конституенткоји је у фокусу издвојен је цртом; у пр. 18 евидентно је да саговорник говори, а питање је о чему. У примерима 19, 20 и 21 топикализовани су адвербијалиначина, узрока, односно времена, који изражавају непознату, при чему у пр. 19 саговорник негира сугестију декларативног питања и наставља одговор као да је реч о одговарајућем заменичком питању. У примеру 22 од интереса је шта је потом било у контексту саговорникових перипетија (а не само јесу ли или нису завршене перипетије).

\footnotetext{
${ }^{4}$ Сродни су и формално неупитни примери типа Занима нас и како факултетски наставници подстичу своје студенте... (Јевтић 2006б: 172) ( $\approx$ Како факултетски наставници подстичу своје студенте?).

${ }^{5}$ Према овом начелу, допринос комуникацији треба да буде информативан онолико колико је потребно за тренутну сврху размене (Грајс 1975: 45).
} 
[15] Да ли су Вас у Београд довеле прилике у тадашњој Независној Држави Хрватској, којој су припала и места Вашег школовања ...? [حШта Вас је довело у Београд?] (Јевтић 1995: 138)

[16] Дакле, следио је повратак? (Јевтић 2003б: 41) [ح Шта је следило?]

[17] Да ли сте и тамо [у Гетеборгу] били - као стипендиста? [ $\approx$ комсвојству сте тамо били?] (Јевтић 2003б: 113)

[18] Говорите о Немачкој? [ح О чему говорите?] (Јевтић 2006а: 100)

[19] - И тако је почео Ваш универзитетски живот? [حКако је почео Ваш универзитетски живот?]

- Не, није баш све тако било ... (Јевтић 2000а: 62)

[20] Да ли сте због тога једно време радили као шумар? [ $\approx$ 3бог чега сте једно време радили као шумар?] (Јевтић 2003a: 11)

[21] Уосталом, да ли сте тада и одлучили да - а било је таквих понуда - не напуштате своју земљу? [Када сте одлучили да ... не напуштате своју земљу?] (Јевтић 2003б: 123)

[22] И тада су, ваљда, биле завршене перипетије? [Шта је тада било (са перипетијама)?] (Јевтић 2003: 137)

2.4. Изборна питања. Изборна питања представљају вид сугестивних питања, јер говорник, заправо, сам сугерише одговоре и тражи од саговорника да прихвати један од сугерисаних одговора. Изборна питања у анализираном корпусу ређа су од да/не питања и заменичких, обично су алтернативна, тј. садрже два сугерисана одговора, и најчешће су, као и друга два главна типа питања (да/не и заменички), део упитног комплекса, као у примеру 23в и 23 д.

[23] [а] Ви сте до сада, углавном, говорили о свом животу и, посебно, о свом редитељском раду. Међутим, Ваш позоришни рад обухвата и друге видове. Рецимо, бавили сте се, и то готово у истој мери, драматизацијама и савремених и класичних текстова.

[б] Шта је једног редитеља нагнало, кажемо то условно, да приђе и тим задужењима?

[в] Да ли је то био знак незадовољства постојећом драмском литературом или, може бити, потреба да у позоришни репертоар унесете и мисао чувених драмских дела?

[г] Како сте у драматизацијама постизали јединство или, барем, склад између мисаоних равни литерарног дела и условљености позоришног чина? 
[д] Уопште, да ли су - како сада на то гледате - драматизације нужно зло савременог позоришта или њен [sic] природан део? [ح Уопште, шта су - како сада на то гледате - драматизације за савремено позориште?] (Јевтић 1997: 36)

Пример 23б несумњиво представља парцијални тип питања, где је узрочник ситуације упитни елемент (обележен упитном заменицом $ш т а$ ). Међутим, и алтернативно питање 23в тражи идентичног узрочника (обележеног анафоричком заменицом то), сугеришући алтернативе, тако да према ситуационом опсегу представља идентичан, парцијални, тип питања. Приметимо да, ако бисмо изоставили један од дисјунката, добили бисмо да/не питање (нпр. Да ли је то био знак незадовољства постојећом драмском литературом?) са фокусом на одговарајућем конституенту задржаног дисјункта (предикативу знак незадовољства ...). Слично је у примеру 23д, где се такође сугеришу алтернативе за један одређени елемент ситуације (својство драматизација), тако да се питање изостављањем тих алтернатива може преформулисати као заменичко ( $и т а)$, или остављањем једне од њих као да/не питање са фокусом, што само потврђује његов карактер парцијалног питања.

Аналогно са да/не питањима са фокусом, може се говорити о типовима изборних питања издвојених на основу реченичних конституената којима одговарају непознати елементи ситуација, при чему одговарајућим типовима да/не питања одговарају идентични типови изборног питања. Примери 23в и 23 д, тако, илуструју предикативна питања, као и пример 24 , где је сугерисано више могућих одговора, при чему је дисјункција обележена и зарезима. У примеру 25 је глаголско предикатско питање (таквог карактера је и питање у пр. 3), чија је пресупозиција да је интервјуисани касније нешто од сугерисаног урадио (у погледу учешћа у политичком организовању...).

[24] Да ли су разлози растурања и распада, а могли бисмо слободно рећи и краха те [СФР] Југославије били начионални, економски, политички, религијски или неки сасвим други, можда сада још недовољно познати? (Јевтић 2001а: 129)

[25] Да ли сте се, касније, повукли или сте наставили да учествујете, директније, и у политичком организовању Срба у тадашњој Хрватској? (Јевтић 1999: 91)

Међутим, у анализираном корпусу врлосу честа изборна питања асиметричног типа, где дисјункти не изражавају опције за непознату паралелно, односно у истој синтаксичкој функцији. Тако, у примеру 26 непознатом елементу одговарају адвербијалне (финалне) клаузе (да бисте - одбранили истину, односно да бисте своје дело учинили ближим, па и популарнијим) у првом дисјункту, а индиректни објекат (о неким другим мотивима) и каузални 
адвербијал (због професионалне или начионалне одговорности и слично) у другом. Слично, у примеру 27 непозната је заступљена у виду индиректног објекта (за уметничке кругове) у првом, а субјекта (млади) у другом дисјункту. Има и случајева где се непознатој у дисјунктима додељује иста синтаксичка функција, уз различиту формулацију познатог дела пропозиције (пример 28).

[26] Да ли то чините да бисте - одбранили истину, односнода бисте своје дело учинили ближим, па и популарнијим или се ради о неким другим мотивима, на пример, због професионалне или нащионалне одговорности и слично? (Јевтић 2008: 103)

[27] Јесу ли југословенске идеје највећма биле везане за уметничке кругове или су млади били основна снага тих стремљења? (Јевтић 1995: 12)

[28] Да ли деци саопштавате у првом реду сећаға на своје детиюство или настојите да и ғихове доживљаје, дакле доживљаје данашъе деце, претачете у песме? (Јевтић 2003а: 59)

Такође, непозната може у једном дисјункту одговарати конституенту, а у другом одговарати читавом том дисјункту, као у примеру 29 , где тај конституент представља адвербијал начина ( $y$ дaxy), који, у смислу непознате,кореспондира са целом другом клаузом, односно другим дисјунктом (уп. ... д даху, или тако што се дуго борите за сваки стих). Слично, у примеру 30 непозната је представљена предикативом у првом дисјункту, односно читавим другим дисјунктом (уп. да ли је то само последица трапавих политичких потеза, или последииа тога што је Црна Гора ...).

[29] Da li je pišete u dahu, ili se dugo borite za svaki stih? (Јевтић 2000в)

[30] U stvari, da li je to [težnja za odvajanjem Crne Gore] samo posledica trapavih političkih poteza, ili je Crna Gora u sadašnjoj jugoslovenskoj zajednici doista neravnopravna? (Јевтић 2000в)

Најзад, непозната може одговарати и читавом првом и читавом потоњем дисјункту, што је практично еквивалентно тоталном (општем) питању, како то одсликава пример 31.Цео пропозитивни садржај у другом, алтернативном, питању делује као нова информација, информација која је у целини упитна, без обзира на то што је реч о елаборацији претходног да/не питања.

[31] Да ли сте, будући глумац који је играо на више сцена у земљи и ван ње, више волели једну публику, а другу, опет, мање? Да ли сте, на пример, више држали до премијерне публике или сте са истом одговорношћу играли и пред њом и пред публиком у неким сасвим малим местима? (Јевтић 2000б: 72) 
Однос дела и целине ситуације, односно релативност појмова дела ицелине ситуације илуструјепример 32 . Алтернативно питање у примеру 32 разрађује претходно заменичко питање, тако што се непозната заменичког питања (како) протеже на целу пропозицију алтернативног питања (уп. како сте размишљали о наредним годинама, односно да ли тако да сте себе виделиза катедром или ...). Другим речима, оно што је парцијално за дато заменичко питање, тотално је за дато алтернативно, које је, опет, парцијално тако да му непознатој одговара месни адвербијал (за катедром / и на неком другом послу).

[32] Уосталом, како сте размишљали о наредним годинама, односно да ли сте себе видели за катедромили, могуће је, и на неком другом послу? (Јевтић 2008: 53)

Пример 33 можда најбоље сведочи о блискости изборних и заменичких питања, поседујући обележја оба типа - дисјункцију (или) и заменички упитни оператор (ко). Дато питање може се парафразирати и у типичној форми изборних питања (Да ли је ... или ...?), а и у типичној форми парцијалних питања, без дисјункције (Који покрет отпора је био ближи тадашьем српском селу?).

[33] Ко је био ближи тадашњем српском селу - четнички или партизански покрет? [= Да ли је тадашњем српском селу био ближи четнички или партизански покрет?] (Јевтић 2003: 33)

С друге стране, некада је, у писању пре свега, нејасно да ли је реч о да/не или алтернативном питању. Пример 34 је интервјуисани или схватио као да/не питање (са фокусом) или је, практично, поништио пресупозицију истинитости само једне од алтернатива алтернативног питања потврдивши обе алтернативе.

[34] - Да ли то говори о немоћи научника или о несхватању науке?

- Постоји једно моје искуство које управо говори о немоћи и несхватаюу науке и научника... (Јевтић 2006б: 98)

\section{3. ЗАКЉУЧАК}

У раду смо пошли од познате поделе питања на општа и посебна, односно тотална и парцијална, при чему се у литератури често као трећи тип издвајају и алтернативна (или, тачније, изборна) питања. Преиспитујући кореспонденцијутих типова са да/не, заменичким и дисјунктивним питањима, указали смо на могућност граматичке синонимије потоња три типа у њиховом функционисању као парцијалних (посебних) питања. 
На трагу, пре свега, Киферовог (1980) истраживања, од да/не питања која се могу појавити у функцији парцијалних идентификовали смо (a)егзистенцијална питања и она која се у том облику могу формулисати, као питања на која је комуникативно неуспешан потврдан одговор сам, и (б) питања са фокусом, као питања на која је комуникативнонедостатан одричан одговор сам. Показује се да у таквимпитањима непознатој може одговарати било који реченични конституент, те се њима, као и заменичким питањима, може тражити информација о било ком елементу комуникативне ситуације.

Утврђено је да изборна питања типичноиспољавају карактер парцијалних, када су еквивалентна да/не питањима са фокусом, која се типичноинтерпретирају као парцијална (изостављањем дисјункта парцијална изборна питања постају парцијална да/не питања са фокусом, односно, увођењем дисјункта парцијална да/не питања са фокусом постају парцијална изборна питања). И парцијална изборнапитања могу се односити на било који аспект ситуације, односно садржај изражен ма којим конституентом. При том, опције за непознату у њима могу бити изражене у истој синтаксичкој функцији у оба дисјункта (други дисјункт је тада најчешће сведен само на део који одговара непознатој), или пак у различитим функцијама. Непозната може у једном дисјункту бити проширенаи на читав тај дисјункт, те - у крајњем случају, рекло би се - изборна питања могу имати карактер тоталних (општих), када је непозната исказана целином оба дисјункта.

\section{ИЗВОРИ}

Јевтић 1990: Милош Јевтић (ур.), Овако говори Матија, Горњи Милановац: Дечје новине.

Јевтић 1991: Милош Јевтић (ур), Са светским славистима, Горњи Милановац: Дечје новине.

Јевтић 1992: Милош Јевтић (ур.), Светови Милића од Мачве, Горњи Милановац - Београд: Дечје новине - Палада.

Јевтић 1994a: Miloš Jevtić (ur.), Dve obale Radomira Putnikovića, Gornji Milanovac: Dečje novine.

Јевтић 1994б: Милош Јевтић (ур.), Десанкина казивања, Горњи Милановац - Београд: Дечје новине.

Јевтић 1995: Милош Јевтић (ур.), Историчари уметности, Београд: Чигоја штампа.

Јевтић 1997: Милош Јевтић (ур.), Сценска поезија Мирослава Беловића, Београд - Ваљево: Орфелин - Кеј. 
Јевтић 1998: Милош Јевтић (ур.), Библиотекари, књ. 1, Београд: Заједница библиотека Србије.

Јевтић 1999: Милош Јевтић (ур.), Остаје прича: разговори са Јованом Радуловићем, Ваљево: Кеј.

Јевтић 2000а: Милош Јевтић (ур.), Видна поља Добросава Цветковића, Београд - Ваљево: Београдска књига - Кеј.

Јевтић 2000б: Милош Јевтић (ур.), Животна Игра Ласла Патакија, Суботица - Београд - Нови Сад: Градска библиотека - Београдска књига - Академија уметности -Позоришни музеј Војводине.

Јевтић 2000в: Miloš Jevtić (ur.), Poreklo nade: razgovori sa Dragomirom Brajkovićem. Riznica srpska. $<\mathrm{http} / /$ riznicasrpska.net/knjizevnost/index. php?topic=352.0;wap2>. 12.9.2016.

Јевтић 2001: Милош Јевтић (ур.), Коридори Ивана Максимовића, Београд: Завод за уџбенике и наставна средства.

Јевтић 2003а:Милош Јевтић (ур.), Мајсторат Душка Трифуновића, Београд - Ваљево: Београдска књига - Беосинг.

Јевтић 2003б: Милош Јевтић (ур.), О микрокосмосу: разговори са Владимиром Пантићем, Београд - Ваљево: Београдска књига - Кеј.

Јевтић 2004: Милош Јевтић (ур.), Трасе Милисава Чутовића, Београд - Ваљево: Београдска књига - Кеј.

Јевтић 2006a: Miloš Jevtić (ur.), Slavistička raskršća Gerharda Neveklovskog, Beograd: Beogradska knjiga

Јевтић 2006б: Милош Јевтић (ур.), Између духа и материје: разговори са Живорадом Чековићем, Београд: Београдска књига.

Јевтић 2008: Милош Јевтић (ур.), Живи звуци Ненада Грујичића, Београд: Београдска књига.

\section{ЛИТЕРАТУРА}

Бартелс ${ }^{2}$ 2013: Christine Bartels, The intonation of English statements and questions: a compositional interpretation, New York - London: Routledge.

Биезма и Ролинс 2012: María Biezma \& Kyle Rawlins, Responding to alternative and polar questions, Linguistics and Philosophy, 35/5, 361-406.

Гандел 1999: Jeanette K. Gundel, On Different Kinds of Focus, in: P. Bosch \& R. van der Sandt (Eds.), Focus: Linguistic, Cognitive, and Com- 
putational Perspectives, Cambridge: Cambridge University Press, 293-305.

Гpajc 1975: Henry Paul Grice, Logic and Conversation, in: P. Cole \& J. L. Morgan (eds.), Syntax and Semantics, Vol. 3, Speech Acts, New York: Academic Press, 41-58.

Јанићијевић 2013: Марко М. Јанићијевић, Интегрална анализа контекстуализације на примеру питања реализованог комплексом реченица, Српски језик, 18/1-2, Београд, 567-577.

Картунен 1977: Lauri Karttunen, Syntax and Semantics of Questions, Linguistics and Philosophy, 1,1-44.

Кифер 1980: Ferenc Kiefer, Yes-No Questions as Wh-Questions, in: J. R. Searle, F. Kiefer \& M. Bierwisch (eds.), Speech Act Theory and Pragmatics, Dordrecht - Boston - London: D. Reidel Publishing Co., 97-120

Ковачевић 2012: Милош Ковачевић, Синтакса и стилистика упитних исказа уроману Господска улииа Ранка Рисојевића, у М. Ковачевић (ред.), Наука и идентитет, том 1, Филолошке науке, Пале: Филозофски факултет, 67-87.

Лајонс 1977: John Lyons, Semantics, Vol. II, Cambridge: Cambridge University Press.

Ламбрехт 1994: Knud Lambrecht, Information structure and sentence form: Topic, focus, and the mental representation of discourse referents, Cambridge: Cambridge University Press.

Левинсон 1983: Stephen C. Levinson, Pragmatics, Cambridge: Cambridge University Press.

Мирић 2013: Dušanka Mirić, Upitni iskaz u ruskom i srpskom jeziku. <http:// digitalna.ff.uns.ac.rs/sites/default/files/db/books/edis02_Miric_ $0 . p d f>$.14.10.2016.

Пипер 2005: Семантичке категорије у простој реченици: синтаксичка семантика, у М. Ивић (ур.) Синтакса савременога српског језика: простареченища, Београд: Институт за српски језик САНУ - Београдска књига - Матица српска, 575-982.

Поповић 2006: Људмила Поповић, Комуникативне функције просте реченице, у М. Ивић (ур.) Синтакса савременога српског језика: проста реченииа, Београд: Институт за српски језик САНУ - Београдска књига - Матица српска, 983-1057.

Свит 2014: Henry Sweet, A New English Grammar: Logical and Historical, Vol. 2, Syntax. <https://www.cambridge.org/core/books/a-new- 
english-grammar/9511BC1CBC71A2D5814BF6A181A6155C > . 15.11.2016.

Станојчић и Поповић 1992: Живојин Станојчић и Љубомир Поповић, Граматика српскога језика, Београд: Завод за уџбенике и наставна средства.

Хадлстон 1994: Rodney Huddleston, The contrast between interrogatives and questions, Journal of Linguistics, 30/2, 411-439.

Холмберг 2015: Anders Holmberg, The syntax of yes and no. $<\mathrm{http}: / /$ recos-dtal. mml.cam.ac.uk/Publications/publications-folder/Holmberg2015The syntaxofyesandno.pdf>. 12.9.2016.

\section{THE YES/NOQUESTIONS AND CHOICE QUESTIONS FUNCTIONING AS PARTIAL (SPECIAL) ONES: A PRAGMALINGUISTIC APPROACH}

\section{Summary}

The goal of the paper is toreexaminethe relationship between certain types of yes/no questions and choice (alternative, disjunctive) questions to the situational scope (total/partial) which their seeked (unknown) information encompasses. The theoretical-methodological framework of the conducted analysis is constituted by linguistic pragmatics - notably, information structure analysis -and syntactic semantics, while the research data is constituted by a significant part of the Collection "Answers", which consists ofbiographically oriented interviews with prominent cultural workers. We establishtypes of yes/no questions which are shown to function as special (partial) questions, regarding situational scope they refer to. We prove that choice questions also exhibit the character of special (partial) questions, and in some cases that of general (total) ones. Hence, in case of special (partial) yes/no and choice questions, one can speak of their grammatical synonymity with Whquestions.

Key words: yes/no questions, choice (alternative) questions, partial (special) questions, pragmatics, information structure, focus, presupposition, indirect utterance.

Marko M. Janićijević 